\title{
Unilateral ischaemic retinopathy and bilateral subdural haemorrhage in an infant with non-accidental injury: An ophthalmological approach
}

\author{
당 Chye Li Ee, M.D., ${ }^{1}$ ๑ Azlindarita Aisyah Mohd Abdullah, MOph, ${ }^{2}$ \\ (1) Amir Samsudin, MOph, PhD, ${ }^{1}$ ㄴ) Nurliza Khaliddin, MOph ${ }^{1}$
}

${ }^{1}$ Department of Ophthalmology, Malaya University Faculty of Medicine, Kuala Lumpur-Malaysia
${ }^{2}$ Department of Ophthalmology, Faculty of Medicine, Universiti Teknologi MARA, Sg Buloh, Selangor-Malaysia

\begin{abstract}
Non-accidental injury (NAI) is not an uncommon problem worldwide, which leads to significant morbidity and mortality in infants. The presence of retinal or subdural haemorrhages, or encephalopathy with injuries inconsistent with the clinical history is highly suggestive of NAI. In this study, we report on a case of a a 3-month-old infant who presented to the casualty department with a very sudden onset of recurrent generalised tonic-clonic seizures. There was no history of trauma or visible external signs. She was found to have bilateral subdural haemorrhages and atypical unilateral ischaemic retinopathy. Retinal photocoagulation was performed with subsequent resolution of vitreous and retinal haemorrhages. However, visual recovery in that eye remained poor. The findings showed that a high index of suspicion of NAl is required in infants with intracranial haemorrhage and unilateral retinal haemorrhages.
\end{abstract}

Keywords: Infant; ischaemic retinopathy; non-accidental injury; subdural haemorrhage; unilateral retinal haemorrhage.

\section{INTRODUCTION}

Non-accidental injury (NAI) is a growing public health problem in the world. In the United States, the annual incidence is estimated to be approximately 35 cases per 100,000 infants in the first year of life. ${ }^{[I]}$ Infants are most commonly affected, with lower frequency in children older than three years of age. ${ }^{[2]}$ In this study, we report an unusual presentation of NAI, in the form of unilateral ischaemic retinopathy and bilateral subdural haemorrhages.

\section{CASE REPORT}

A 3-month-old infant girl with normal development was brought to the casualty department with three episodes of tonic-clonic seizures. There was no history of falls or head trauma. She was being cared by a baby-sitter when she first developed the seizures. Computed tomography showed subdural haemorrhage bilaterally, with both sides requiring burr holes and drainage surgery (Fig. I). The ophthalmological evaluation revealed a vitreous haemorrhage, as well as preretinal and intra-retinal haemorrhages with peripheral vascular sheathing in the left eye (Fig. 2). Fundus examination of the right eye was normal.

There was no bruising on the head or body, and systemic examination was otherwise normal. She was admitted to the paediatric intensive care unit after the initial decompression surgery. Serological investigations for syphilis, rubella, toxoplasma cytomegalovirus and herpes virus were negative, and there were no organisms cultured from her cerebrospinal fluid sample. Skeletal survey was normal. Serial eye examinations were conducted during the hospital stay, but the view

Cite this article as: Ee CL, Abdullah AAM, Samsudin A, Khaliddin N. Unilateral ischaemic retinopathy and bilateral subdural haemorrhage in an infant with non-accidental injury: An ophthalmological approach. Ulus Travma Acil Cerrahi Derg 2019;25:527-530.

Address for correspondence: Chye Li Ee, M.D.

Department of Ophthalmology, Faculty of Medicine, University of Malaya, 50603 Kuala Lumpur - Malaysia

Tel: +60379492060 E-mail: eechyeli@gmail.com

Ulus Travma Acil Cerrahi Derg 2019;25(5):527-530 DOI: 10.5505/tjtes.2018.57059 Submitted: 05.09.2018 Accepted: 05.1I.2018 Online: 06.08.2019

Copyright 2019 Turkish Association of Trauma and Emergency Surgery 


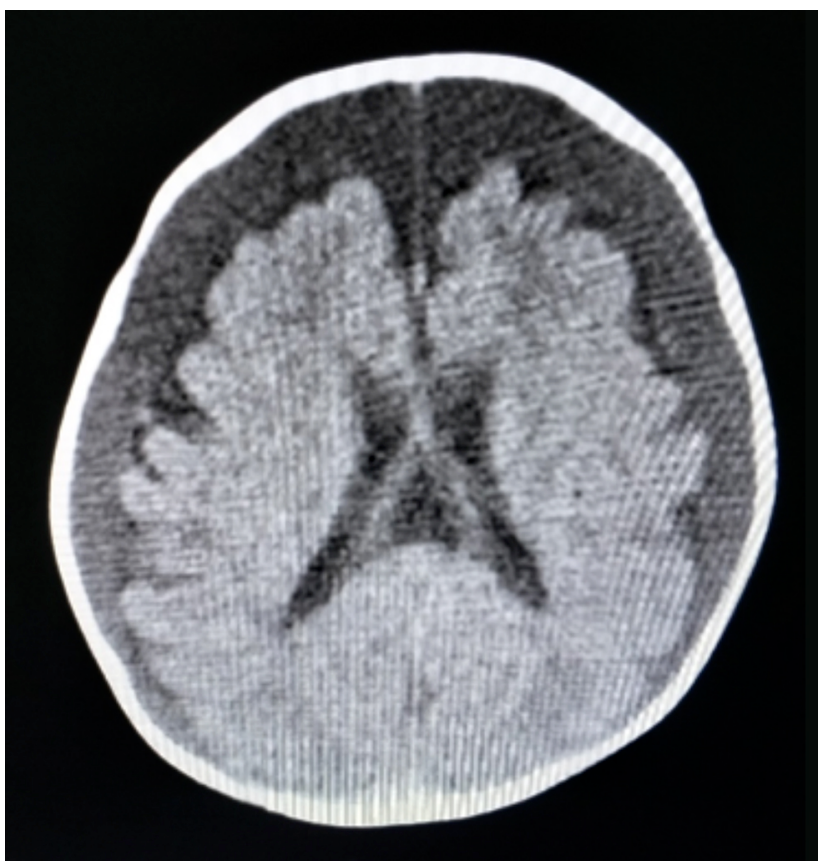

Figure 1. Computed tomography showing bilateral fronto-parietaltemporal chronic subdural haemorrhage.

of the left fundus was obscured by the vitreous haemorrhage. Six weeks later, an examination under anaesthesia (EUA) was performed. The vitreous haemorrhage cleared up, but there were signs of ischaemia with generalised peripheral neovascularisation, areas of pre-retinal haemorrhage and vascular sheathing of the left eye. An aqueous tap was sent for cytomegalovirus and syphilis PCR, which came back negative. After obtaining consent from the parents, pan-retinal photocoagulation was performed to ablate the ischaemic retina to reduce vascular endothelial growth factor drive and to treat the neovascularisation. The parents were informed that the treatment was not to restore vision but instead to prevent future complications, such as rubeotic glaucoma and the development of a painful blind eye.

A second EUA with additional laser ablation was performed on the left eye two weeks after the first EUA as there was residual neovascularisation with peripheral pre-retinal haemorrhages. A week following the second retinal photocoagulation, she developed esotropia and a relative afferent pupil defect in her left eye. The fundus examination five months after the initial presentation revealed a pale optic disc with fibrovascular proliferation both nasally and superotemporally (Fig. 3).

\section{DISCUSSION}

Clinical distinction between non-accidental and accidental injuries in infants is challenging. According to Maguire et al., ${ }^{[3]}$
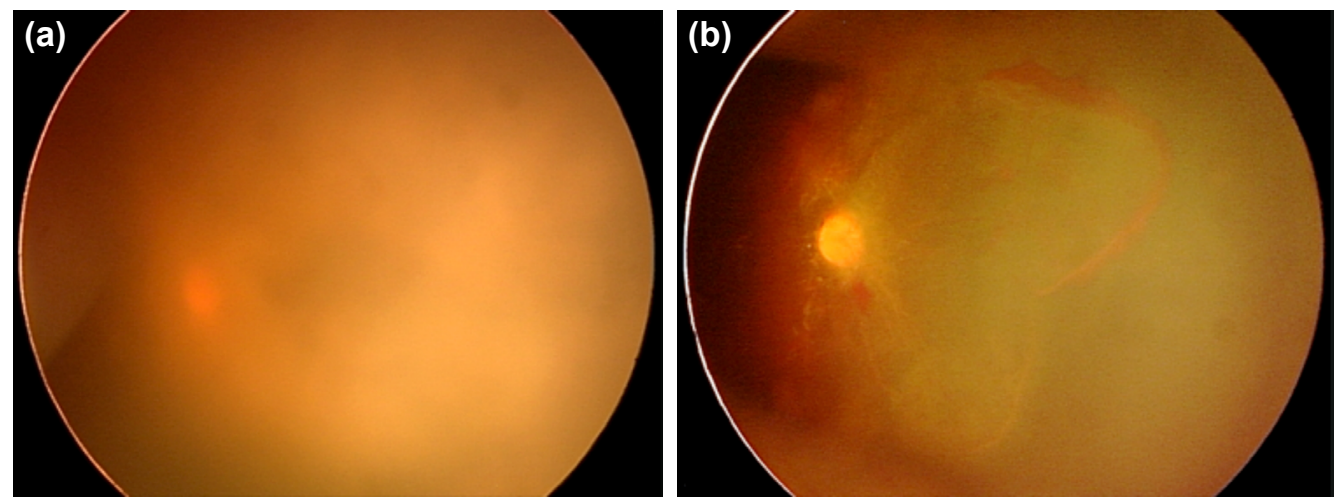

Figure 2. Fundus photo of the left eye showing (a) diffuse vitreous haemorrhage obscuring details of optic disc and retina at the time of presentation, and (b) extensive pre-retinal and intra-retinal haemorrhages nasal to the optic disc, and along the superotemporal and inferotemporal arcades a month after presentation.
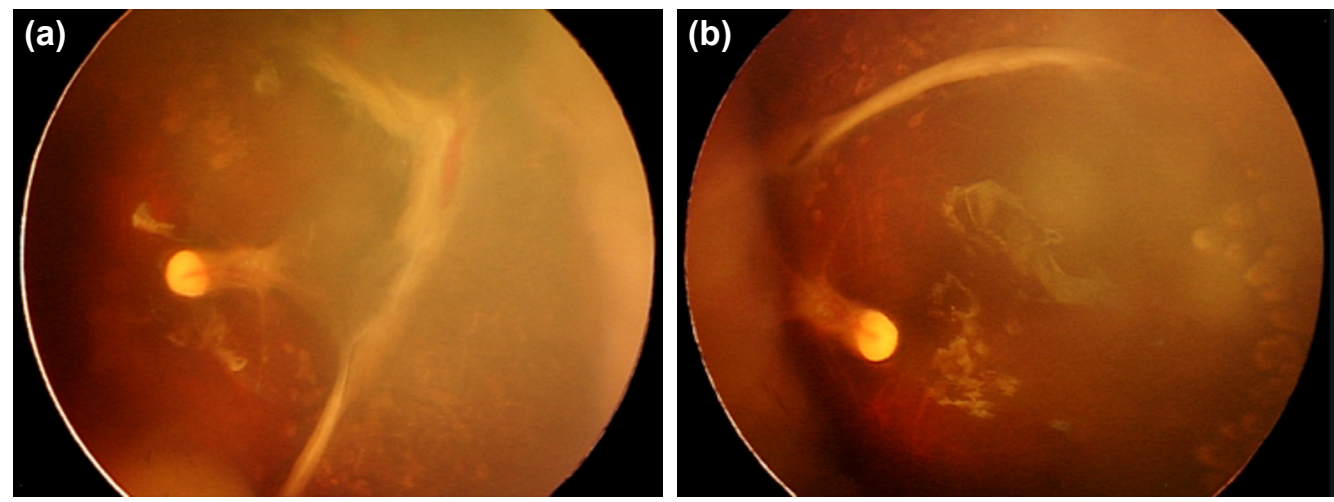

Figure 3. Fundus photo of the left eye three months post panretinal photocoagulation showing optic disc pallor with fibrovascular proliferation and traction (a) nasal to the optic disc, and (b) along the superotemporal arcade. 
presence of subdural haemorrhage, retinal haemorrhage, apnoea or rib fractures are highly suggestive, although not exclusive to NAl. Cutaneous bruises of varying colours and long bone fractures at different stages of healing also increase the likelihood of NAI. However, the absence of visible external injuries or fractures does not exclude the possibility of NAI, such as in this infant. A meticulous history, detailed physical examination, as well as exclusion of possible organic causes (e.g. osteogenesis imperfecta and clotting abnormalities) are the key points in diagnosing NAI.

Retinal haemorrhages are the most common ocular manifestation of NAI and are found in up to $85 \%$ of cases. ${ }^{[4]}$ Other ophthalmic signs of NAl include periorbital haematoma, subconjunctival haemorrhage, subluxated or dislocated lens, retinal dialysis or detachment, and intraocular haemorrhage. When associated with a head injury, it is most often due to inflicted, rather than accidental injury, especially in infants less than I-year old. Retinal haemorrhages in NAl are usually bilateral, multi-layered and extend to the periphery, unlike in the case described above, which presented with only unilateral retinal haemorrhages. ${ }^{[5]}$ These haemorrhages are likely to be due to repetitive acceleration-deceleration forces causing vitreomacular traction, raised intracranial pressure, increased central venous pressure, hypoxia, or coagulopathies. ${ }^{[6]}$ Seizures alone are unlikely to bring about retinal haemorrhages, with a likelihood of less than $1 \% .{ }^{[7]}$ The most common site of retinal haemorrhages is near to the ora serrata $(40 \%)$, followed by the disc and macula (20\%). ${ }^{[5]}$ In this case, the bleeding occurred at the peripheral, as well as macula areas of the retina.

Buys et al. ${ }^{[8]}$ carried out a prospective study involving 79 children under the age of 3 years with head injuries. They found out that 75 children who sustained accidental head injuries due to falls from height did not have any retinal haemorrhages. However, retinal haemorrhages were present in all four children with NAI. This finding correlates well with the results we obtained from our infant in the present study, who most likely had a non- accidental injury rather than a fall.

Other possible causes of retinal haemorrhages in infants include accidental head injury, Purtscher retinopathy, coagulopathy, retinopathy of prematurity, intracranial vascular malformation and infections, which should be excluded before the diagnosis of NAl. ${ }^{[9]}$ Pathogens, such as herpes simplex virus, cytomegalovirus, toxoplasmosis, Neisseria meningitidis, Streptococcus pneumoniae, Staphylococcus spp., Brucella spp. and Candida albicans, have been reported to be associated with retinal haemorrhages. These retinal haemorrhages are often bilateral, with concomitant signs of systemic infection. Agrawal et al. ${ }^{[10]}$ reported that children with infection and sepsis often showed fewer than five haemorrhages per fundus. An infectious aetiology is highly unlikely to be the cause of unilateral ischaemic retinopathy in this case, as evidenced by negative serological, as well as aqueous culture and PCR results. Biochemical investigations in this patient were also unremarkable, excluding the possibility of coagulopathy as the cause of retinal haemorrhages and subdural haemorrhage.

Tyagi et al. ${ }^{[1]}$ published three cases of unilateral retinal haemorrhages in NAl. They described spontaneous and complete resolution of intraocular haemorrhages in all the infants but with consequent poor vision in two of them due to the associated optic nerve and occipital lobe injury. The infant in our case also had poor visual prognosis given the optic atrophy and relative afferent pupillary defect.

Unilateral retinal haemorrhages do not exclude the possibility of NAI, although the latter is commonly associated with bilateral involvement. The presence of retinal haemorrhages and subdural haemorrhage in children strongly suggest NAI. However, other causes of retinal haemorrhages should be ruled out first due to significant social and legal implications. Maintaining an appropriate differential diagnosis could minimise the likelihood of misdiagnosis of child abuse.

\section{Conflict of interest: None declared.}

\section{REFERENCES}

1. Joyce T, Huecker MR. Pediatric Abusive Head Trauma (Shaken Baby Syndrome). Treasure Island (FL): StatPearls Publishing; 2019.

2. Watts P; Child maltreatment guideline working party of Royal College of Ophthalmologists UK. Abusive head trauma and the eye in infancy. Eye (Lond) 2013;27:1227-9. [CrossRef]

3. Maguire S, Pickerd N, Farewell D, Mann M, Tempest V, Kemp AM. Which clinical features distinguish inflicted from non-inflicted brain injury? A systematic review. Arch Dis Child 2009;94:860-7. [CrossRef]

4. Kivlin JD, Simons KB, Lazoritz S, Ruttum MS. Shaken baby syndrome. Ophthalmology 2000;107:1246-54. [CrossRef]

5. Aryan HE, Ghosheh FR, Jandial R, Levy ML. Retinal hemorrhage and pediatric brain injury: etiology and review of the literature. J Clin Neurosci 2005;12:624-31. [CrossRef]

6. Levin AV. Retinal hemorrhage in abusive head trauma. Pediatrics 2010;126:961-70. [CrossRef]

7. Mei-Zahav M, Uziel Y, Raz J, Ginot N, Wolach B, Fainmesser P. Convulsions and retinal haemorrhage: should we look further? Arch Dis Child 2002;86:334-5. [CrossRef]

8. Buys YM, Levin AV, Enzenauer RW, Elder JE, Letourneau MA, Humphreys RP, et al. Retinal findings after head trauma in infants and young children. Ophthalmology 1992;99:1718-23. [CrossRef]

9. Kaur B, Taylor D. Fundus hemorrhages in infancy. Surv Ophthalmol 1992;37:1-17. [CrossRef]

10. Agrawal S, Peters MJ, Adams GG, Pierce CM. Prevalence of retinal hemorrhages in critically ill children. Pediatrics 2012;129:e1388-96. [CrossRef]

11. Tyagi AK, Willshaw HE, Ainsworth JR. Unilateral retinal haemorrhages in non-accidental injury. Lancet 1997;349:1224. [CrossRef] 


\section{OLGU SUNUMU - ÖZET}

\section{Kaza sonucu oluşmamış, yaralı bebekte tel taraflı iskemik retinopati ve iki taraflı subdural kanama: Bir oftalmolojik yaklaşım \\ Dr. Chye Li Ee, ${ }^{1}$ Dr. Azlindarita Aisyah Mohd Abdullah, ${ }^{2}$ Dr. Amir Samsudin, ${ }^{1}$ Dr. Nurliza Khaliddin}

Malaya Üniversitesi Tıp Fakültesi, Göz Hastalıkları Bölümü, Kuala Lumpur-Malezya Universiti Teknologi MARA Tıp Fakültesi, Göz Hastalıkları Bölümü, SG Buloh, Selangor-Malezya

Kaza sonucu oluşmayan yaralanma (KSOY) dünya ölçeğinde sık görülmeyen bir sorun olup bebeklerde önemli morbidite ve mortaliteye yol açmaktadır. Klinik öyküyle uyumlu olmayan retina veya subdural kanamaların veya ensefalopatinin varlığı yüksek olasılıkla KSOY'yi düşündürür. Bu çalışmada acil servise çok hızlı başlangıçı yinelenen generalize tonik-klonik nöbetlerle gelen üç aylık bir bebeği raporluyoruz. Travma öyküsü veya dışardan görünür belirti yoktu. Kız bebekte iki taraflı subdural kanamalar ve atipik tek taraflı iskemik retinopati saptanmıştır. Retinal fotokoagülasyon uygulaması sonucu vitröz ve retina kanamalarının kaybolduğu görülmüştür. Ancak bu gözde görme pek geri dönmemiştir. Bulgular, intrakranyal kanama ve tek taraflı retina kanamaları olan bebeklerde yüksek olasılıkla KSOY'den kuşkulanılması gerektiğini göstermiştir. Anahtar sözcükler: İnfant; iskemik retinopati; kaza sonucu oluşmamış yaralanma; subdural kanama; tek taraflı retina kanaması.

Ulus Travma Acil Cerrahi Derg 2019;25(5):527-530 doi: 10.5505/tites.2018.57059 